\title{
Synthesis and Characterization of N-(2- acetylthiophene) salicylideneimine (ATS) as Ionophore for Polymeric Membrane Ag (I) Selective Electrode
}

Eman H. Abd Elnasser, Manara A. Ayoub\#, Mona. A. Ahmed and Mariam G.R.

Chemistry Department, Women's College for Arts, Science and Education, Ain Shams University, Cairo, P.O. BOX 11757, Egypt.

\begin{abstract}
A NOVEL silver ion selective membrane electrode which was $\mathrm{A}_{\text {based on a newly synthesized N-(2-acetylthiophene) }}$ salicylicdeneimine (ATS) by the reaction of 2-acetyl thiophene with 2-aminophenol at $60^{\circ} \mathrm{C}$ in ethanol by using ultrasound irradiation. ATS was characterized by elemental analyses, FTIR, MS and ${ }^{1} \mathrm{H}-$ NMR.The best performance was obtained for the membrane of composition (ATS): PVC: DOS in the ratio 1:33:66 wt \%. The sensor shows a linear potential response for $\mathrm{Ag}^{+}$over a wide concentration range $6.0 \times 10^{-8}-1.0 \times 10^{-1} \mathrm{M}$ and detection limit $4.36 \times 10^{-8}$ with Nernstian slope $\left(57.93 \mathrm{mV}\right.$ decade $^{-1}$ of activity) between a wide $\mathrm{pH}$ range (3.0-10) and a fast response time of 10s. The selectivity coefficient values were calculated with separate solution method, which indicate good selectivity of $\mathrm{Ag}^{+}$ion. The sensor has a lifetime of five weeks and could be used as an indicator electrode in the potentiometric titration of $\mathrm{Ag}^{+}$vs. stander solution of $\mathrm{NaCl}$ and in the estimation of $\mathrm{Ag}^{+}$in photographic solutions and medical X-ray samples.
\end{abstract}

Keywords: Poly vinyl chloride (PVC), N-(2-acetylthiophene) salicylideneimine (ATS), Silver selective sensor and Nernstian slope.

Silver (I) ion has been used in a wide range of products such as electronic products, alloys, jewelry and photographic film. Also due to its antibacterial effect, accelerating would healing and anti-inflammatory properties, silver and its compounds have been applied in the medical and health care field ${ }^{(1)}$. Silver salts have also been used to disinfect water used for drinking and recreational purposes, in dental and pharmaceutical antibacterial ${ }^{(2)}$. However, it is also well known that silver inactivates sulfhyldryl enzymes, combines with amine, imidazole and carboxyl groups of various metabolites. It has been found that an excess of silver is toxic to fish and microorganisms at a concentration as low as $0.17 \mu \mathrm{g} / \mathrm{l}^{(3)}$. Thus, the increasing use of silver compounds in industry and medicine has resulted in an increased silver content of environmental samples.

\#Corresponding author e mail address: Manara_2005@yahoo.com 
On the other hand, superfluous silver and its compounds have toxic effect on both human and animal health. Consequently, determination of the trace amount of silver ions in samples is necessary. Several techniques such as atomic absorption spectroscopy ${ }^{(4,5)}$ inductively coupled plasma mass spectroscopy ${ }^{(6-9)}$ and flow injection analysis ${ }^{(10,11)}$ are used for its determination at low concentration level. There has been a growing interest in the development and application of potentiometric sensors for monitoring concentration of various species in biological, environmental, and industrial fields. Because of their unique advantages such as fast response, ease of preparation, low cost, possibility of using in complex and color media, wide linear dynamic range, relatively low detection limit, and adequate selectivity for most analyses ${ }^{(12)}$. Thus, a number of $\operatorname{Ag}(\mathrm{I})$ sensor based on crown ethers ${ }^{(13-15)}$ calix[4]arene derivatives ${ }^{(16-18)}$, bispyridinetetramidemacrocycle $^{(19)}$ bis(dialkyldithiophosphate) derivative ${ }^{(20)}$ and bis(thiothiazole)derivative ${ }^{(21)}$ Schiff bases ${ }^{(22,23)}$ in PVC have been reported. It is well known that the soft heavy metal ions, $\mathrm{Ag}$ (I), $\mathrm{Pb}$ (II) and $\mathrm{Hg}$ (II) display great affinity for soft coordination centers like sulfur and nitrogen. By using ionophores containing sulfur and nitrogen atoms in ion selective electrodes, the electrode are sensitive to soft heavy metal ions and the selectivity for soft heavy metal ions against alkali metal ions is significantly increased ${ }^{(24)}$. In this study, we utilized N-(2-acetylthiophene) salicylideneimine (ATS) ionophore, as Schiff base selective carrier for silver ions. The results obtained with (ATS) based on silver electrodes showed high selectivity coefficients for silver ion over all the studied alkali, alkaline, transition ions and heavy metal ions.

\section{Experimental}

\section{Equipments}

Elemental microanalyses of the separated Schiff base for C, H, N and S were performed in Main Defense Chemical Laboratory, Almaza, Cairo, Egypt. The FTIR spectra $\left(400-4000 \mathrm{~cm}^{-1}\right)$ of the compound was recorded as $\mathrm{KBr}$ discs using a Shimadzu 8000 FTIR spectrometer at the central laboratory, Ain Shams University, Cairo, Egypt. ${ }^{1} \mathrm{H}-\mathrm{NMR}$ spectra recorded using a Varian spectrometer, $300 \mathrm{MHz}$ in Main Defense Chemical Laboratory. All potentiometric measurements were performed at room temperature using $\mathrm{pH} / \mathrm{mV}$ meter [Orion model A 720], double junction $\mathrm{Ag} / \mathrm{AgCl}$ reference electrode [Orion model 90-02] containing $10 \% \mathrm{KNO}_{3}$ in the outer compartment. Combination glass electrode [Orion model 8-02] was used for all $\mathrm{pH}$ measurements.

$\mathrm{Ag} / \mathrm{AgCl} /$ internal solution $(1 \mathrm{mM} \mathrm{NaCl}$ in acetate buffer $\mathrm{pH}=4.0) / \mathrm{PVC}$ membrane / test solutions / $\mathrm{AgCl}, \mathrm{Ag}$

\section{Reagents and materials}

2-acetylthiophene was obtained from Merck, and 2-aminophenol was obtained from Aldrich (USA). Solvents and reagents were purified and dried by distillation. High molecular weight poly vinyl chloride (PVC), 2-ethyl sebacate (DOS), potassium tetrakis (4-chlorophenyl) borate (KTpClPB) and 
tetrahydrofuran (THF), o-nitrophenyloctylether (O-NPOE), dioctylphthalate (DOP) were obtained fluke (Ronkonkoma, NY). All other reagents used as purchased without further purification. Deionized water was used in the preparation of buffer solutions. $0.1 \mathrm{M}$ stock solutions were prepared by dissolving AR grade metal nitrates solution in buffer solutions and standardized wherever necessary. The working solutions of different concentration were prepared by stock solution.

Syntheses of N-(2-acetylthiophene) salicylideneimine Schiff base (ATS)

The ligand was synthesized by slow addition of 2 -acetylthiophene $(0.33 \mathrm{ml}, 3$ mmole) in $30 \mathrm{ml}$ ethanol to 2-aminophenol (0.327 gm, 3 mmole) in $30 \mathrm{ml}$ ethanol. The reaction mixture was heated to reflex at $60^{\circ} \mathrm{C}$ and subjected to ultrasound irradiation to for $2 \mathrm{hr}$. The brown product obtained after cooling was filtered off and washed with few amounts of ethanol then diethylether. Fine crystals were obtained by recrystallization from hot ethanol. The yield was (0.526gm, $74.60 \%)$, m.p. $\left(157-159^{\circ} \mathrm{C}\right)$.

Anal. Calcd. For $\mathrm{C}_{12} \mathrm{H}_{11} \mathrm{NSO}$ : C, 66.36; H, 5.07; N, 6.45; S, 14.75.Found: C, $66.40 ; \mathrm{H}, 4.87$; N, 6.60; S, 14.60\%. Infrared spectrum ( $\mathrm{cm}^{-1} \mathrm{KBr}$ disk); 3304 (v.s)

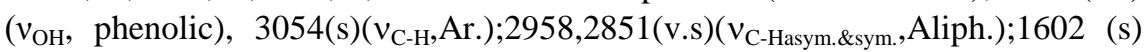
$\left(v_{\mathrm{C}=\mathrm{N}}\right.$, azomethine);1141 (s) ( $v_{\mathrm{C}-\mathrm{O}}$, phenolic); 1467(m) ( $\left.v_{\mathrm{C}=\mathrm{C}}, \mathrm{Ar}.\right) ; 743(\mathrm{v} . \mathrm{s})\left(v_{\mathrm{C}-\mathrm{S}}\right.$, thiophenolic).

$\left({ }^{1} \mathrm{H}-\mathrm{NMR}, \mathrm{DMSO}-\mathrm{d}^{6}, \mathrm{ppm}\right) ; \delta 3.172\left(\mathrm{~s}, 3 \mathrm{H}, \mathrm{CH}_{3}\right), 6.358-6.986(\mathrm{~m}, 4 \mathrm{H}, \mathrm{Ar}-$ $\mathrm{H}), 7.365-7.722(\mathrm{~m}, 3 \mathrm{H}$, thiophene protons), $8.879(\mathrm{~s}, 1 \mathrm{H}, \mathrm{OH}) . \mathrm{MS}(\mathrm{m} / \mathrm{z}, \%)$; $217\left(\mathrm{M}^{+}, 70.4\right) ; 57$ (100), 69 (65.17), 76 (12.36), 82 (12.36), 94 (60.67), 107 (76.40), 134 (61.80), 175 (64.04), 175 (64.04), 187 (60.67) and 202 (65.17). The reaction for the formation of (ATS) is illustrated in Scheme 1.

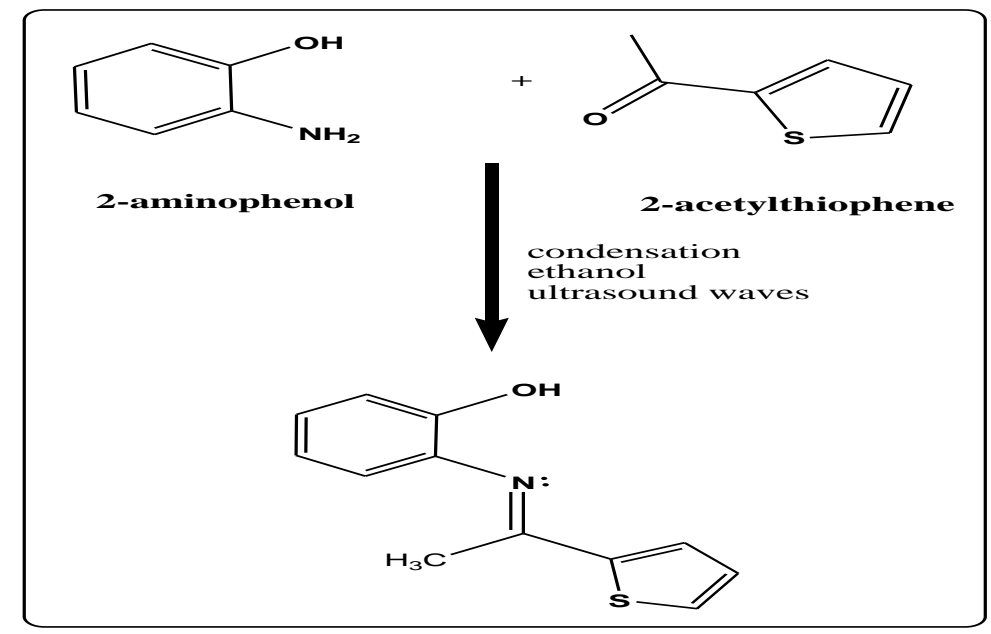

Scheme 1. Schematic representation for the formation of Schiff base ligand, (ATS). Egypt. J. Chem. 59, No.6 (2016) 


\section{Membrane preparation}

The PVC based membranes were prepared as described elsewhere ${ }^{(25)}$, by dissolving appropriate amounts of Schiff base (TAS), anion excluder KTpCIPB, solvent mediators 2-nitrophenyloctylether (NPOE), dioctyl phthalate (DOP), 2-ethyl sebacate (DOS) and appropriate amount of PVC in THF $(2 \mathrm{~mL})$. After complete dissolution of all the components and thorough mixing, the resultant cocktail was transferred to a glass ring placed on a glass plate. Membranes were formed after controlled evaporation of THF at room temperature overnight. A flexible, transparent membrane of a thickness of $\sim 0.2-0.4 \mathrm{~mm}$ was obtained. The discs of $7 \mathrm{~mm}$ diameter were cut using a cork borer, and then were glued to a PVC tip which was clipped to the end of the electrode body. The PVC membrane electrodes were pre-conditioned by immersion in a $1 \mathrm{mM} \mathrm{NaCl}$ for at least $24 \mathrm{hr}$ prior to use. Membranes of different compositions were prepared and investigated. Those, which gave reproducible results and best performance characteristics, were selected for detailed studies. The optimum compositions of best performing membranes are given in (Table 1).

\section{Sample pretreatment}

The waste photographic and medical $\mathrm{x}$-Ray films solutions were prepared for the measurement of their silver content as follows. $20 \mathrm{ml}$ of the sample was added to $10 \mathrm{ml}$ of $3 \mathrm{M}$ nitric acid and $40 \mathrm{ml}$ distilled water. The solution was boiled for $1 \mathrm{hr}$. min until its volume was reduced to half of its original values. The resulting solution was neutralized with sodium hydroxide solution to a $\mathrm{pH} 4.0$, and filtered. The filtrate and washings were diluted to $100 \mathrm{ml}$ in a volumetric flask with acetate buffer $\mathrm{pH} 4.0$ and used for potentiometric and atomic absorption measurements. A portion of the film sample $2.0 \mathrm{~g}$ was mixed with $5 \mathrm{ml}$ of concentrated $\mathrm{HNO}_{3}$ and $50 \mathrm{ml}$ water and boiled for $\sim 1 \mathrm{~h}$. The resulting mixture was then filtered and the filtrate was neutralized with $1 \mathrm{M}$ sodium hydroxide solution and diluted to $100 \mathrm{ml}$ using acetate buffer $\mathrm{pH}$ 4.0.

\section{Results and Discussion}

Influence of membrane composition on the potentiometric response

The influence of addition of various mol \% anionic sites (relative to ATS ionophore) and using different types of plasticizers (o-NPOE, DOP and DOS) were investigated. Surprisingly we found that all membranes $\left(E_{1}, E_{2}\right)$ formulated with high polarity plasticizers o-NPOE and DOP and $\left(\mathrm{E}_{4}, \mathrm{E}_{5}\right)$ formulated with DOS (with anionic additives) exhibited minimal cationic response to all cations investigated including primary ion (silver). As depicted in (Table 1\& Fig. 1), membrane sensor plasticized with low polarity DOS ( $E_{3}$ without additives) showed better response slopes. This is consistent with literature finding that polymeric membrane of low-polarity exhibited improved responses toward monovalent cations ${ }^{(26)}$. 


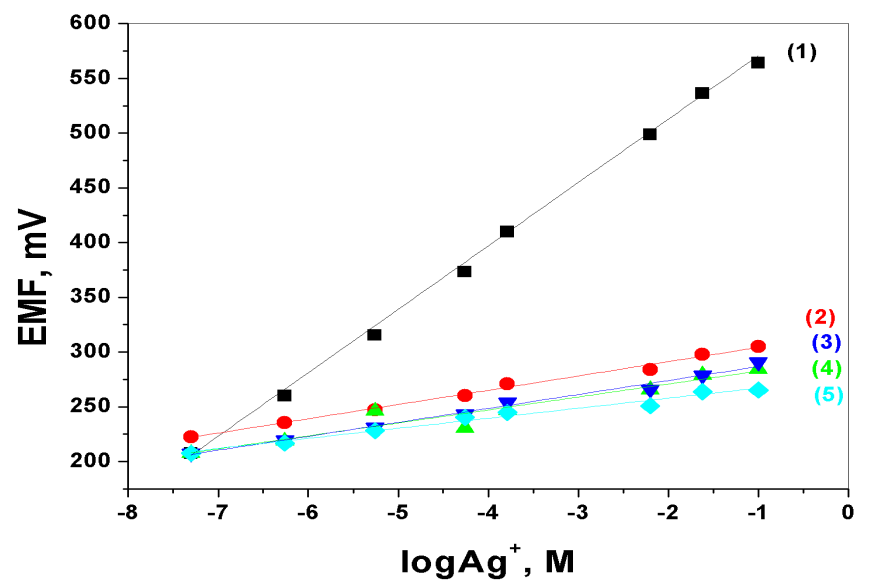

Fig. 1. Potentiometric response, measured in $50 \mathrm{mM}$ acetate buffer $\mathrm{pH} 4.0$, of various compositions of ATS-based membrane electrode toward silver ions: $\mathrm{E}_{3}(1)$, $E_{4}(2), E_{5}(3), E_{1}(4), E_{2}(5)$.

TABLE 1. Effect of the plasticizer type and addition of ionic sites on the response characteristics of silver membrane electrodes based on ATS ionophore.

\begin{tabular}{|c|c|c|c|c|c|c|c|c|c|}
\hline \multirow[t]{2}{*}{$\begin{array}{c}\text { Electrode } \\
\text { No. }\end{array}$} & \multicolumn{5}{|c|}{ Membrane Composition } & \multirow{2}{*}{$\begin{array}{c}\text { Slope } \\
\text { mV/ } \\
\text { decade }\end{array}$} & \multirow{2}{*}{$\begin{array}{c}\text { Linear Range } \\
\mathbf{M}\end{array}$} & \multirow{2}{*}{$\begin{array}{c}\text { Detection } \\
\text { limit } \\
M\end{array}$} & \multirow[t]{2}{*}{$\mathbf{R}^{2}$} \\
\hline & $\begin{array}{l}\text { PU } \\
\text { mg }\end{array}$ & $\begin{array}{c}\text { PVC } \\
\text { mg } \\
\end{array}$ & \begin{tabular}{|c|} 
Plasticizer \\
$(132 \mathrm{mg})$ \\
\end{tabular} & $\begin{array}{c}\text { ATS } \\
\text { mg }\end{array}$ & \begin{tabular}{|c|} 
(TClPB) \\
$\mathrm{mol} \%$
\end{tabular} & & & & \\
\hline$E_{1}$ & - & 66 & o-NPOE & 2 & $\ldots \ldots$ & 12.75 & $6.0 \times 10^{-8}-1.0 \times 10^{-1}$ & $4.89 \times 10^{-8}$ & 0.991 \\
\hline $\mathrm{E}_{2}$ & - & 66 & DOP & 2 & $\ldots$. & 9.16 & $6.0 \times 10^{-8}-1.0 \times 10^{-1}$ & $5.13 \times 10^{-8}$ & 0.983 \\
\hline$E_{3}$ & - & 66 & DOS & 2 & $\ldots \ldots$ & 57.93 & $6.0 \times 10^{-8}-1.0 \times 10^{-1}$ & $4.36 \times 10^{-8}$ & 0.992 \\
\hline $\mathrm{E}_{4}$ & - & 66 & DOS & 2 & 10 & 13.03 & $1.0 \times 10^{-7}-1.0 \times 10^{-1}$ & $5.13 \times 10^{-8}$ & 0.981 \\
\hline$E_{5}$ & - & 66 & DOS & 2 & 50 & 12.54 & $5.0 \times 10^{-8}-1.0 \times 10^{-1}$ & $4.47 \times 10^{-8}$ & 0.958 \\
\hline
\end{tabular}

$\mathrm{R}^{2}$ : Correlation coefficient

Selectivity coefficients of optimized silver ion-sensor

The potentiometric selectivity of the optimized sensor was investigated for several ions and the selectivity coefficients were calculated using separated sample solution method $(\mathrm{SSM})^{(12)}$. The cationic response of the optimized potentiometric sensor $\left(\mathrm{E}_{3}\right)$ towards various cations is shown in Fig. 2, and the selectivity coefficient is shown in Table 2. As can be seen optimized potentiometric sensor $\left(\mathrm{E}_{3}\right)$ exhibited high selectivity for $\mathrm{Ag}^{+}$ion over a number of monovalent, divalent and trivalent cations, also the optimal membrane sensor showed remarkably better selectivity in comparison with membrane sensor prepared with anionic sites $\left(\mathrm{E}_{4}\right.$ and $\left.\mathrm{E}_{5}\right)$. This result agreed very well with the view that the soft coordination site of sulfur offers great affinity towards silver which is soft $\left(\mathrm{d}^{10}\right)$ transition metal ion ${ }^{(27) .}$ 


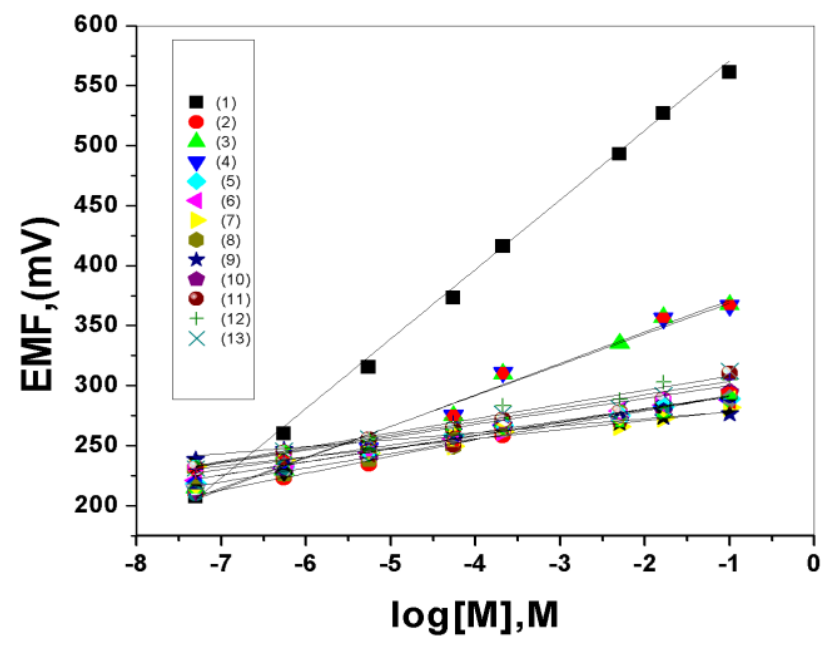

Fig. 2. Potentiometric response of ATS-based silver-selective membrane electrode $\mathbf{E}_{3}$, measured in $50 \mathrm{mM}$ acetate buffer $\mathrm{pH} 4.0$ towards various metal ions : $\operatorname{Ag}^{+}(1)$, $\mathrm{Li}^{+}(2), \mathrm{Na}^{+}(3), \mathrm{Hg}^{2+}(4), \mathrm{Cu}^{2+}(5), \mathrm{Pb}^{2+}(6), \mathrm{Mn}^{2+}(7), \mathrm{Zn}^{2+}(8), \mathrm{Ni}^{2+}(9), \mathrm{Co}^{2+}(10)$, $\mathrm{Al}^{3+}(11), \mathrm{Sr}^{3+}(12), \mathrm{Cr}^{3+}(13)$.

TABLE 2. Selectivity coefficients $\log K_{A g+X^{n+}}^{\text {pot }}$ for optimized silver-membrane sensor $\mathrm{E}_{3}$ measured in $0.05 \mathrm{M}$ acetate buffer, $\mathrm{pH}$ 4.0.

\begin{tabular}{|l|c|}
\hline Metal ion & $\log \mathbf{K}_{\mathbf{A g}}^{\mathbf{p o t}}{ }^{+} \mathbf{x}^{\mathbf{n +}}$ \\
\hline $\mathrm{Li}^{+}$ & -4.4 \\
\hline $\mathrm{Na}^{+}$ & -4.8 \\
\hline $\mathrm{Hg}^{2+}$ & -4.9 \\
\hline $\mathrm{Cu}^{2+}$ & -5.2 \\
\hline $\mathrm{Pb}^{2+}$ & -5.2 \\
\hline $\mathrm{Mn}^{2+}$ & -5.2 \\
\hline $\mathrm{Zn}^{2+}$ & -5.2 \\
\hline $\mathrm{Ni}^{2+}$ & -5.2 \\
\hline $\mathrm{Co}^{2+}$ & -5.5 \\
\hline $\mathrm{Al}^{3+}$ & -5.6 \\
\hline $\mathrm{Sr}^{3+}$ & -5.7 \\
\hline $\mathrm{Cr}^{3+}$ & -5.9 \\
\hline
\end{tabular}

Egypt. J. Chem. 59, No.6 (2016) 


\section{Effect of $p H$}

The $\mathrm{pH}$ dependence of the optimized membrane sensor $\left(\mathrm{E}_{3}\right)$ was investigated at two concentrations of $\mathrm{Ag}^{+}\left(1.0 \times 10^{-3}\right.$ and $\left.1.0 \times 10^{-4} \mathrm{M}\right)$ solution over a $\mathrm{pH}$ range of 2 to 11 and the results obtained are given in Fig. 3. It is seen from this figure that the potential remains constant over a $\mathrm{pH}$ range of 3 to 10 . This means that the optimized sensor can be used to measure a wide range of environmental and industrial water samples without $\mathrm{pH}$ adjustment.

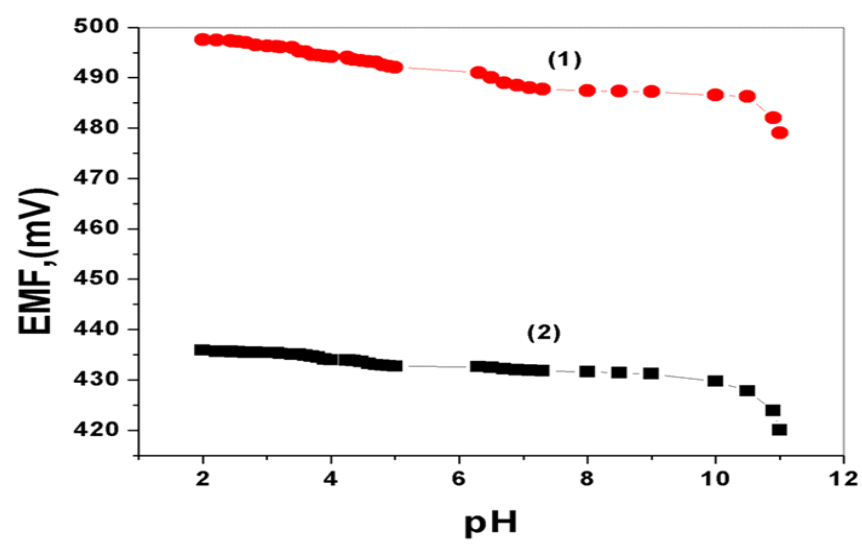

Fig. 3. Effect of $\mathrm{pH}$ on the potentiometric response of optimized membrane electrode $E_{3}$ measured in $50 \mathrm{mM}$ acetate buffer $\mathrm{pH} 4.0$, in the presence of $1.0 \times 10^{-3} \mathrm{M}(1)$ and $1.0 \times 10^{-4} \mathrm{M}(2)$ of $\mathrm{AgNO}_{3}$.

Response mechanism and lifetime

Figure 4, shows the response time of the optimized sensor $\left(E_{3}\right)$ when exposed to increasing silver ion concentrations from $1.0 \mu \mathrm{M}$ to $0.1 \mathrm{M}$ in $50 \mathrm{mM}$ acetate buffer, $\mathrm{pH}$ 4.0. As can be seen, over the investigated concentration range, the optimized sensors reached to the equilibrium response in a very short time $(<10 \mathrm{~s})$. The life time of the optimized membrane electrodes was found to have the same slope with deviation of $\pm 4 \mathrm{mV} /$ decade over a period of five week.

\section{Potentiometric titration}

The optimized selective membrane sensor $\left(E_{3}\right)$ was utilized as an indicator electrode in the potentiometric titration of different concentrations of silver ions with standard sodium chloride solution. Typical titration curves with sharp inflection breaks were obtained as can be seen in Fig. 5. The signal change at the inflection breaks was found to be in the range $390-470 \mathrm{mV}$ depending on the starting silver ion concentration.

\section{Analytical application}

The optimized of the ATS-based silver electrode was further assessed by measuring the silver ion concentrations in acetate buffered, $\mathrm{pH}=4$ photographic solution samples and medical $\mathrm{x}$-Ray films. Comparison of these results with the data obtained using atomic absorption spectrometry (AAS) showed very good agreement as shown in Table 3. 


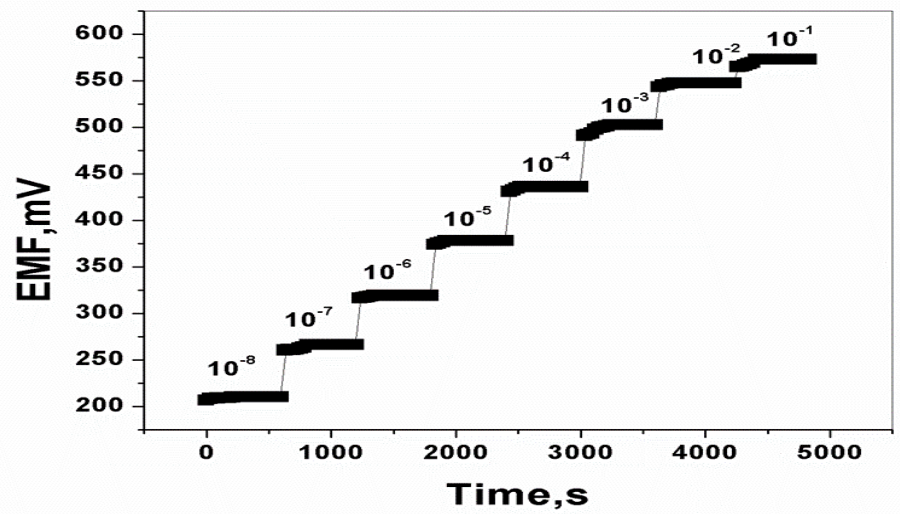

Fig. 4. Typical response time of optimized electrode $E_{3}$ measured in $50 \mathrm{mM}$ acetate buffer, $\mathrm{pH} 4.0$ at different silver concentrations

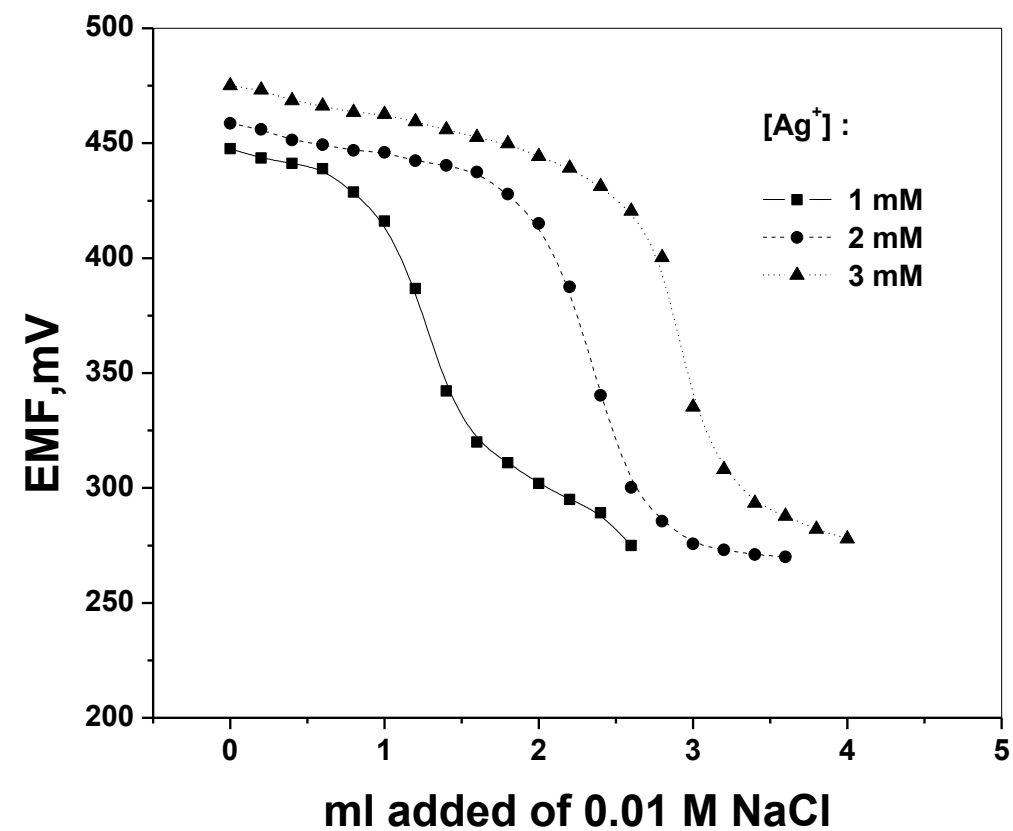

Fig. 5. Typical potentiometric titrations of different amount of silver ions with standard sodium chloride solution monitored using optimized membrane electrode $\mathbf{E}_{3}$.

Egypt. J. Chem. 59, No.6 (2016) 
Synthesis and Characterization of N-(2-acetylthiophene) salicylideneimine ...

TABLE 3. Determination of $\mathrm{Ag}^{+}$ions in photographic and $\mathrm{x}$-rays samples using optimized sensor $\left(E_{3}\right)$ in comparison with standard atomic absorption method.

\begin{tabular}{|lccc|}
\hline Real samples & $\begin{array}{c}\mathbf{A A S} \pm \mathbf{S D}^{\mathbf{a}} \\
\mathbf{m g} / \mathbf{l}\end{array}$ & $\begin{array}{c}\text { Potentiometry } \pm \mathbf{S D}^{\mathbf{a}} \\
\mathbf{m g} / \mathbf{l}\end{array}$ & $\begin{array}{c}\text { Recovery } \\
\mathbf{\%}\end{array}$ \\
\hline Fixing solutions & & & \\
A & $11.9 \pm 0.4$ & $11.6 \pm 0.4$ & 97.47 \\
B & $6.3 \pm 0.9$ & $6.17 \pm 1$ & 97.94 \\
\hline Medical X-rays & & & \\
A & & $2.03 \pm 0.4$ & 98.54 \\
B & $2.06 \pm 0.3$ & $3.47 \pm 0.5$ & 100.00 \\
\hline
\end{tabular}

a : Mean value \pm standard deviation (SD) \{two determinations \}.

b: $2 \mathrm{mg}$ samples were dissolved in $10 \mathrm{ml}$ solution.

\section{Conclusion}

The investigations demonstrate the utility of the membrane sensor incorporating $\mathrm{N}$-(2-acetylthiophene)salicylideneimine (ATS) as ionophore in determining $\mathrm{Ag}^{+}$in the concentration range $6.0 \times 10^{-8}-1.0 \times 10^{-1} \mathrm{M}$. The functional $\mathrm{pH}$ range is 3.0 to 10 . It could be used as an indicator electrode in the potentiometric titration of $\mathrm{Ag}^{+}$ions with $\mathrm{NaCl}$ solution. Analytical application shows that it holds promise for regular and routine analysis of $\mathrm{Ag}^{+}$in diverse samples. It exhibits good reproducibility, fast response time and can be used for five week.

\section{References}

1. Akram, D., Mohammad, K.R. and Mohammad, H.M., Synthesis and characterization of $\mathrm{N}, \mathrm{N}^{\prime}$-bis(benzophenoneimine)formamidine as ionophores for silver-selective electrodes. Sensors and Actuators B: Chem. 202, 410-416 (2014).

2. Zhang, X.B., Han, Z.X., Fang, Z.H., Shen, G.L. and Yu, R.Q., 5, 10, 15-Tris (pentafluorophenyl) corrole as highly selective neutral carrier for a silver ionsensitive electrode. Anal. Chim. Acta, 562(2), 210 (2006).

3. Wygladacz, K., Radu, A., Xu, C., Qin, Y. and Bakker, E., Fiber-optic micro sensor array based on fluorescent bulk optode microspheres for the trace analysis of silver ions. Anal. Chem. 77(15), 4706-4712 (2005).

4. Pu, Q. and Sun, Q., Application of 2-mercaptobenzothiazole-modified silica gel to on-line preconcentration and separation of silver for its atomic absorption spectrometric determination. Analyst, 123, 239-243 (1998).

5. Manzoori, J.L., Abdol mohammad-Zadeh, H. and Amjadi, M., Ultra-trace determination of silver in water samples by electro thermal atomic absorption spectrometry after preconcentration with a ligand-less cloud point extraction

Egypt. J. Chem. 59, No.6 (2016) 
methodology. Haza J. Materials, 144, 458 (2007).

6. Laborda, F., Jiménez-Lamana, J., Boleaa, E. and Castillo, J.R., Selective identification, characterization and determination of dissolved silver(I) and silver nanoparticles based on single particle detection by inductively coupled plasma mass spectrometry. J. Anal. Atomic Spectrometry, 26, 1362-1371 (2011).

7. Krachler, M., Mohl, C., Emons, H. and Shotyk, W., Analytical procedures for the determination of selected trace elements in peat and plant samples by inductively coupled plasma mass spectrometry. Spectrochim. Acta B, 57, 1277-1289 (2002).

8. Wang, T., Jia, X. and Wu, J., Direct determination of metals in organics by inductively coupled plasma atomic emission spectrometry in aqueous matrices, J. Pharm. Biomed. Anal. 33(4), 639-646 (2003).

9. Yang, X.J., Foley, R. and Low, G.K.C., A modified digestion procedure for analyzing silver in environmental water samples. Analyst, 127, 315-318 (2002).

10. Williamson, J.P. and Emmert, G.L., A flow injection analysis system for monitoring silver (I) ion and iodine residuals in recycled water from recovery systems used for spaceflight. Anal. Chim. Acta, 792, 72 (2013).

11. Dole, A.J., Cardwell, T.J., Cattrall, R.W., Digiacomo, R., Rodrigues, C.G. and Scollary, G.R., The Determination of silver in photographic emulsions by discontinuous flow analysis. Electroanalysis, 10, 21 (1998).

12. Bakker, E., Bühlmann, P. and Pretsch, E., Carrier based ion selective electrodes and bulk optodes. 1. general characteristics. Chem. Rev. 97 (8), 3083-3132 (1997).

13. Casabo, J., Teixidor, F., Escriche, L., Vinas, C. and Jimenez, C.P., Silvers elective electrodes based on supported liquid membranes. Adv. Mater. 7, 238 (1995).

14. Su, C.C., Chang, M.C. and Liu, L.K., New $\mathrm{Ag}^{+}$and $\mathrm{Pb}^{2+}$ selective electrodes with lariat crown ethers as ionophores. Anal. Chim. Acta, 432(2), 261-267 (2001).

15. Goldcamp, M.J., Ashley, K., Edison, S.E., Pretty, J. and Shumaker, J., A bisoxime derivative of diaza-18-crown-6 as an ionophore for silver ion. Electroanalysis, 17, 10151018 (2005).

16. Kimura, K., Yajima, S., Tatsumi, K., Yokoyama, M. and Oue, M., Silver ion selective electrodes using pi-coordinate calix. Anal. Chem. 72(21), 5290-5294 (2000).

17. Chen, L.X., Ju, H.F., Zeng, X.S., He, X.W and Zhang, Z.Z., Silver ion-selective electrodes based on novel containing benzothiazolyl calix[4]arene. Anal. Chim. Acta, 437 (2), 191-197 (2001).

18. Ceresa, A., Radu, A., Peper, S., Bakker, E. and Pretsch, E., Rational design of potentiometric trace level ion sensors $\mathrm{Ag}^{+}$selective electrode with a $100 \mathrm{ppt}$ detection limit. Anal. Chem. 74 (16), 4027-4036 (2002).

19. Mahajan, R. K. and Parkash, O., Silver (I) ion selective PVC membrane based on bis-pyridine tetramidemacrocycle. Talanta, 52 (4), 691-693 (2000).

Egypt. J. Chem. 59, No.6 (2016) 
Synthesis and Characterization of N-(2-acetylthiophene) salicylideneimine ..

20. Liu, D., Liu, J., Tian, D., Hong, W., Zhou, X. and Yu, J.C., Polymeric membrane silver-ion selective electrodes based on bis(dialkyldithiophosphates). Anal. Chim. Acta, 416 (2), 139-144 (2000).

21. Badr, I.H.A., A New neutral carrier for filverions based on a bis(Thiothiazole) derivative and its evaluation in membrane electrodes. Microchim. Acta, 149(1), 87-94 (2005).

22. Hassouna, M.E.M., Elsuccary, S.A.A. and Graham, J.P., $N, N^{\prime}$-Bis(3-methyl-1phenyl-4-benzylidine-5-pyrazolone)propylenediamine Schiff base as a neutral carrier for silver (I) ion-selective electrodes. Sensors and Actuators B, 146 (1), 79-90 (2010).

23. Dadkhah, A., Rofouei, M.K. and Mashhadizadeh, M.H., Synthesis and characterization of $\mathrm{N}, \mathrm{N}^{\prime}$-bis(benzophenoneimine)formamidine as ionophores for silver-selective electrodes. Sensors and Actuators B, 202, 410-416 (2014).

24. Pearson, R.G., Hard and Soft Acids and Bases. J. Am. Chem. Soc. 85(22), 3533- 3539 (1963).

25. Badr, I.H.A., Diaz, M., Hawthorne, M.F. and Bachas, L.G., Mercuracarborand "anti-crown ether" based chloride sensitive liquid/polymeric membrane electrodes. Anal. Chem. 71(7), 1371-1377 (1999).

26. Ammann, D., Morf, W.E., Anker, P., Meier, P.C., Pretsch, E. and Simon, W. Ion-Selective Electrode Rev. 5, 3 (1983).

27. Casabo, J., Teixidor, F., Escriche, L., Vinas, C. and Jimenez, C.P., Silver-selective electrodes based on supported liquid membranes. Adv. Mater. 7, 238-243 (1995).

(Received 12/10/2016 ;

accepted 18/12/2016) 


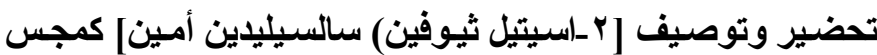 غشائى لتقدير الجها الكهربي لعنصر الفضه
}

ايمان حامد عبد الناصر، مناره احمد أيوب، منى عبد العزيزأحمد و مريم جرجس رزق ائل

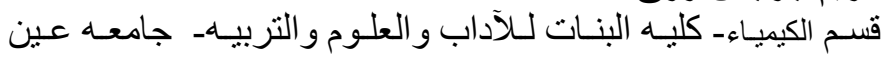

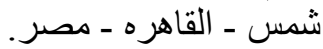

\begin{abstract}
تحضير مجس غشائى جديد لتقدير الجهد الكهربي لعنصر الفضأه ـ وهذا المجس

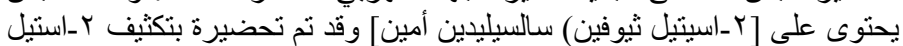

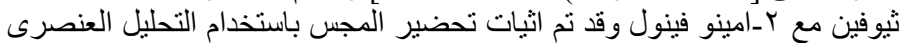

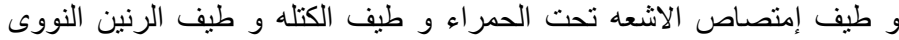

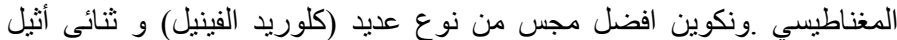

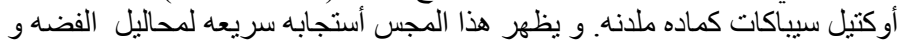

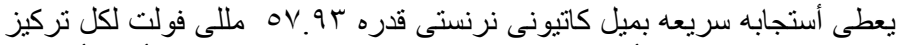

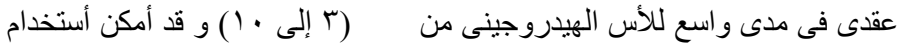

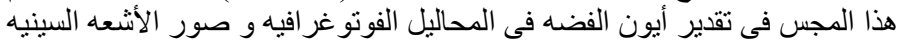

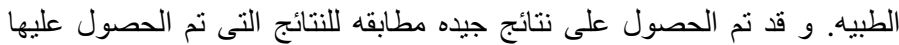
بأستخدام قياس طيف الأمنصاص الذرى لأيون لتان الفضه كطريقه قياسيه.
\end{abstract}

